\title{
Methylation status and chromatin structure of the myostatin gene promoter region in the sea perch Lateolabrax japonicus (Perciformes)
}

\author{
E.M. Abbas ${ }^{1}$, A. Takayanagi ${ }^{2,3}$, N. Shimizu ${ }^{3}$ and M. Kato ${ }^{1}$ \\ ${ }^{1}$ Department of Biological Science, Graduate School of Science, \\ Osaka Prefecture University, Sakai, Japan \\ ${ }^{2}$ Department of Molecular Biology, \\ Keio University School of Medicine, Tokyo, Japan \\ ${ }^{3}$ Advanced Research Center for GSP, Keio University, Tsukuba, Japan \\ Corresponding author: M. Kato \\ E-mail: mkato@b.s.osakafu-u.ac.jp / mikio_kato@mac.com
}

Genet. Mol. Res. 10 (4): 3306-3315 (2011)

Received May 20, 2011

Accepted July 26, 2011

Published December 8, 2011

DOI http://dx.doi.org/10.4238/2011.December.8.7

\begin{abstract}
Myostatin is a negative regulator of the growth and development of skeletal muscle mass. In fish, myostatin is expressed in several organs in addition to skeletal muscle. To understand the mechanisms regulating myostatin gene expression in the sea perch, Lateolabrax japonicus, we examined the methylation status of the myostatin gene promoter region in several tissues (liver, eye, kidney, brain, and heart) isolated from adult specimens. The frequency of methylated cytosines was very low in all tissues, regardless of the level of myostatin expression, suggesting that DNA methylation is not involved in the tissue-specific regulation of myostatin expression. Southern blot analysis of genomic DNA obtained from micrococcal nucleasetreated nuclei showed that chromatin digestion occurs in tissues where the myostatin gene is actively transcribed and that the myostatin gene is protected from micrococcal nuclease in tissues where myostatin is not expressed. The chromatin structure in the myostatin gene region
\end{abstract}


appears to regulate its expression without DNA methylation.

Key words: Chromatin; DNA methylation; Fish; Micrococcal nuclease; Myostatin

\section{INTRODUCTION}

Myostatin, also known as growth differentiation factor 8, is a member of the transforming growth factor (TGF- $\beta$ ) superfamily, which negatively regulates the growth and development of skeletal muscle mass (Lee, 2004). In mammals, myostatin is expressed almost exclusively in skeletal muscle. On the other hand, myostatin appears to be more ubiquitously expressed in fish, suggesting that its contributions to the growth and development of fish are more diverse (Radaelli et al., 2003; Helterline et al., 2007). Consistent with this idea, teleost fishes possess at least two myostatin genes, which are differentially expressed in both muscle and non-muscle tissues, whereas myostatin is encoded by a single gene in mammals (Biga et al., 2005; Kerr et al., 2005; Østbye et al., 2007). Myostatin cDNA has been characterized in a number of commercially important fishes, including rainbow trout (Rescan et al., 2001), Atlantic salmon (Østbye et al., 2001), Mozambique tilapia (Rodgers and Weber, 2001), white bass and striped bass (Rodgers et al., 2001), gilthead sea bream (Maccatrozzo et al., 2001a), catfish (Gregory et al., 2004) and grouper (Ko et al., 2007), among others; and expression of myostatin mRNA has been detected in a variety of tissues and at different stages of development in some fish species (Rescan et al., 2001; Østbye et al., 2001; Rodgers and Weber, 2001; Maccatrozzo et al., 2001a,b; Kocabas et al., 2002; Roberts and Goetz, 2003; Vianello et al., 2003; Xu et al., 2003; Gregory et al., 2004; Ko et al., 2007). Interestingly, Acosta et al. (2005) reported that silencing the myostatin gene produces a giant phenotype in zebrafish, while Lee et al. (2009) showed that the suppression of myostatin with vector-based RNA interference causes a doublemuscle effect resulting from hypertrophy in transgenic zebrafish, and Sawatari et al. (2010) recently showed that the introduction of a dominant-negative form of myostatin into the medaka fish Oryzias latipes leads to a doubling of the number of its muscle fibers.

Several potential cis-acting elements needed for transcriptional activity have been identified in the promoter region of myostatin gene in the gilthead sea bream Sparus aurata (Funkenstein et al., 2009). In addition, Ye et al. (2007) identified cis-acting elements in the 5' flanking region of myostatin, which may contribute to the tissue specificity of the transcriptional activity of myostatin gene in the sea perch Lateolabrax japonicus. However, gene expression also reflects the status of the chromatin (euchromatin or heterochromatin) in the region where the gene is situated. The status of chromatin in particular gene regions is dynamically modulated to control gene expression and other fundamental cellular processes, such as cell proliferation and differentiation (Li, 2002; Felsenfeld and Groudine, 2003; Jaenisch and Bird, 2003).

DNA methylation at cytosine residues is involved in epigenetic regulation that is closely related to heterochromatinization, which suppresses gene expression (Goll and Bestor, 2005; Klose and Bird, 2006; Reik, 2007; Kuroda et al., 2009; Zhang et al., 2010). Furthermore, the myostatin gene promoter regions in a group of closely related fish (belonging to the suborder Percoidei) are highly conserved and contain several $\mathrm{CpG}$ dinucleotides within the conserved regions, which could serve as targets for DNA methylation (Figure 1). To better understand the mechanisms regulating myostatin gene expression in fish, we analyzed 
the chromatin structure using micrococcal nuclease (MNase) as an enzymatic probe. We also assessed the methylation status of the promoter region of myostatin genes in various tissues from L. japonicus.

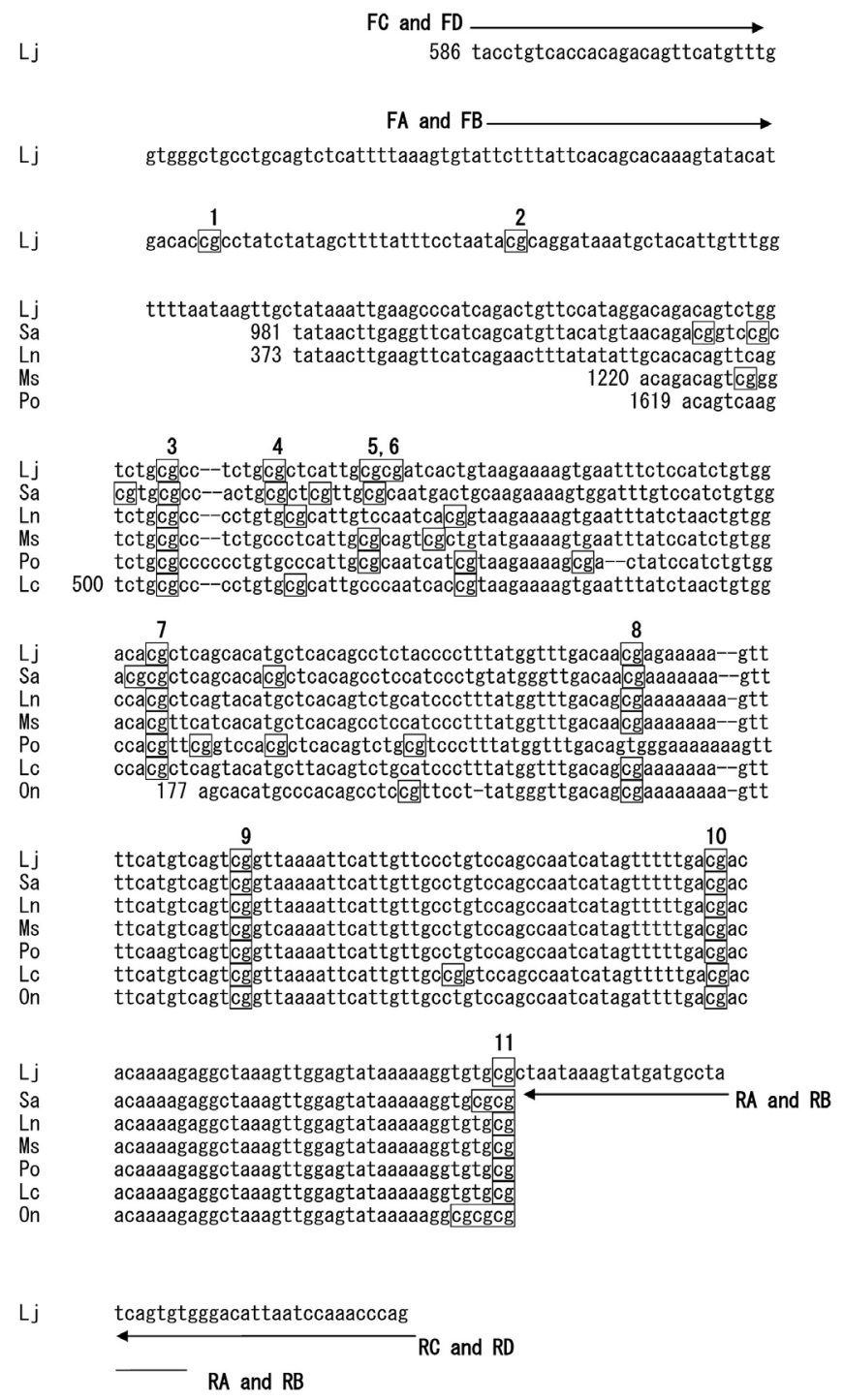

Figure 1. Conserved sequences in the myostatin gene 5 ' flanking region. Homologous sequences were retrieved from GenBank databases and aligned to identify conserved regions. Sequences are numbered according to the original sequence data. $\mathrm{Lj}=$ Lateolabrax japonicus (Genbank accession No. AY965685); Sa $=$ Sparus aurata (EU881511); Ln = Lates niloticus $(\mathrm{EF681885);} \mathrm{Ms} \mathrm{=} \mathrm{Micropterus} \mathrm{salmoides}(\mathrm{EF} 071854) ;$ Po = Paralichthys olivaceus (DQ997779); Lc = Lates calcarifer (EF672685); On = Oreochromis niloticus (FJ972683). CpG sites are boxed, and those analyzed by bisulfite sequencing are indicated above the lines (from numbers 1 to 11). Primer sites for methylation analysis are shown by arrows with bold face characters. Primer names (FA, FB, FC, FD, RA, $\mathrm{RB}, \mathrm{RC}$, and $\mathrm{RD}$ ) refer to Table 1. 


\section{MATERIAL AND METHODS}

\section{DNA primers}

The oligonucleotides used as PCR primers are listed in Table 1. Primers were designed to amplify bisulfite-treated genomic DNA, or were used to amplify the probe for Southern blot hybridization.

\begin{tabular}{llc}
\multicolumn{2}{l}{ Table 1. Oligonucleotides used as PCR primers. } \\
\hline Primer name & Sequence (5'- $\left.3^{\prime}\right)$ & Position in AY965685 \\
\hline FA & TTCTTTATTCACAACACAAAATATACAT & $647-674$ \\
FB & TTTTTTATTTATAGTATAAAGTATATAT & $647-674$ \\
RA & ATATTGATAGGTATTATATTTTATTAG & $1023-1049$ \\
RB & ACACTAATAAACATCATACTTTATTAA & $1023-1049$ \\
FC & TACCTATCACCACAAACAATTCATATTT & $586-613$ \\
FD & TATTTGTTATTATAGATAGTTATGTTT & $586-613$ \\
RC & TTGGGTTTGGATTAATGTTTTATATTGA & $1043-1060$ \\
RD & CTAAATTTAAATTAATATCCCACACTAA & $1043-1060$ \\
LjaMSTNP2F & CCTATCTATAGCTTTTATTTCCTAATA & $682-708$ \\
LjaMSTNR1 & CACACCTTTTTATACTCCAACTTTA & $986-1010$ \\
\hline Names, sequences and targeted genomic regions are shown
\end{tabular}

Names, sequences and targeted genomic regions are shown.

\section{Nucleus preparation and MNase treatment}

Fish samples (40 to $60 \mathrm{~cm}$ standard length) were purchased from a fish market at Izumisano Port, Osaka, Japan, and stored at $-80^{\circ} \mathrm{C}$ before use. Individual fish were dissected after thawing under running tap water, and selected tissues (liver, eye, kidney, brain, and heart) were isolated. Each tissue was homogenized using a Teflon homogenizer in TES buffer (10 $\mathrm{mM}$ Tris-HCl, $140 \mathrm{mM} \mathrm{NaCl}, 25 \mathrm{mM}$ EDTA, $\mathrm{pH}$ 7.8), after which cells were harvested by centrifugation at $3000 \mathrm{~g}$ for $10 \mathrm{~min}$. The cell pellets were then resuspended in the same buffer and centrifuged again. The resultant washed cells were suspended in 10 volumes (relative to the packed-cell volume) of hypotonic buffer (10 mM Tris- $\mathrm{HCl}, 15 \mathrm{mM} \mathrm{KCl}, 0.5 \mathrm{mM}$ $\mathrm{MgCl}_{2}, \mathrm{pH} 7.8$ ) and left on ice for $10 \mathrm{~min}$. Once swollen, the cells were centrifuged at 1000 $g$, and the cell pellet was resuspended in 5 volumes of hypotonic buffer. The cells were then homogenized using a Dounce glass homogenizer (B-pestle), and the nuclei were harvested by centrifugation and resuspended in the hypotonic buffer. MNase (Sigma-Aldrich) was added to the nucleus suspensions $\left(40 \mu \mathrm{g} / \mathrm{mL}\right.$ ), after which the mixtures were incubated at $37^{\circ} \mathrm{C}$ for 15 , 30 or $60 \mathrm{~min}$, and one-third of the original reaction volumes was collected at each time. The nuclease reactions were terminated by adding aliquots ( $1 / 20$ of the reaction volume) of $0.5 \mathrm{M}$ EDTA, after which the DNA was isolated from each reaction mixture.

\section{Isolation of genomic DNA from MNase-treated cell nuclei}

An equal volume of TES buffer containing $1 \%$ SDS and $0.5 \mathrm{mg} / \mathrm{mL}$ Proteinase $\mathrm{K}$ (Invitrogen Life Technologies) was added to the MNase-treated nuclei mentioned above, after which the reaction mixtures were incubated for $30 \mathrm{~min}$ at $50^{\circ} \mathrm{C}$. The DNA was then extracted using phenol, precipitated with ethanol and dissolved in TE buffer $(10 \mathrm{mM}$ Tris $\mathrm{HCl}, 1 \mathrm{mM}$ 
EDTA, $\mathrm{pH}$ 7.8). Total DNA isolated from the MNase-treated nuclei was digested using the restriction endonuclease TaqI (Takara-Bio), separated on 1.2\% agarose gel electrophoresis and subjected to Southern blot hybridization.

\section{Southern blot hybridization}

The separated DNA on the agarose gels was transferred to nylon membranes $\left(\right.$ Hybond $^{\mathrm{TM}}-\mathrm{N}^{+}$, Amersham Biosciences) using the capillary blot procedure (Southern, 1975), and was probed for the promoter region of the myostatin gene from L. japonicus. The probe was then labeled using a PCR DIG Probe Synthesis kit (Roche) with a pair of DNA primers, LjaMSTNP2F and LjaMSTNR1.

\section{Bisulfite treatment of genomic DNA and sequencing}

Fish were dissected, and tissue samples from brain, kidney, spleen, liver, heart, eye, muscle, intestine, and gills were homogenized in TES buffer, after which the total genomic DNA was isolated as previously described (Sambrook and Russell, 2001). Samples of genomic DNA were then digested with EcoRI (New England Biolabs), and the resultant DNA fragments (500 ng) were subjected to bisulfite modification using an EZ DNA Methylation-Gold kit (Zymo Research). Bisulfite treatment converts cytosines to uracils, but 5-methylcytocines remain intact. Thus, the combination of bisulfite treatment and following PCR enabled us to detect methylated cytosines occurring in genomic DNA (Clark et al., 1994). A set of primers (FC and RC) was used for PCR to amplify the antisense strand of the bisulfite-treated DNA, while another set of primers (FD and RD) was used for PCR to amplify the sense strand of bisulfite-treated DNA. Each PCR product was then subjected to a second PCR with a set of nested primers: FA and RA for antisense strand amplification and FB and RB for sense strand amplification. The PCR was performed using the Ampli Taq Gold 2X PCR Master Mix (Applied Biosystems) with a GeneAmp PCR System 9700 (Applied Biosystems). The amplification protocol entailed initial denaturation at $95^{\circ} \mathrm{C}$ for $2 \mathrm{~min}$ followed by 35 cycles of $95^{\circ} \mathrm{C}$ for $30 \mathrm{~s}, 50^{\circ} \mathrm{C}$ for $30 \mathrm{~s}$ and $72^{\circ} \mathrm{C}$ for $2 \mathrm{~min}$, and a final elongation at $72^{\circ} \mathrm{C}$ for $7 \mathrm{~min}$. The resultant PCR products were cloned into the HincII site of pUC118 vector. DNA sequencing was performed using the Big Dye Terminator ver. 3.1 Cycle Sequencing kit (Applied Biosystems) and ABI3730 Sequencer (Applied Biosystems).

\section{RESULTS}

\section{Bisulfite modification of genomic DNA to evaluate the methylation status}

We initially determined the nucleotide sequences of the PCR products obtained with bisulfite-treated DNA (5-18 clones each from the respective samples) (Tables 2 and 3). The efficiency of the bisulfite modification (conversion of $\mathrm{C}$ to $\mathrm{T}$ ) was estimated by counting the numbers of cytosines remaining at $\mathrm{CpNs}(\mathrm{N} \neq \mathrm{G})$, and the conversion frequency was found to be $99 \%$ or higher. The number of cytosine residues remaining at $\mathrm{CpGs}$ appeared to be above the background level in the sense strands from eye and heart (methylation frequency: 6.36 and $5.68 \%$, respectively), but were at the background level in the complementary strands from these tissues. This may indicate that the methylation frequency was within the error range of 
the random sampling. In any case, the frequency of methylated cytosine was very low in the tissues examined, regardless of the level of myostatin gene expression. This runs counter to the suggestion drawn from the results of Ye at al. (2007), and may mean that $\mathrm{CpG}$ methylation is not involved in regulating myostatin gene expression in L. japonicus.

Table 2. Summary of bisulfite sequencing: relative percentage of unconverted bases after bisulfite treatment.

\begin{tabular}{lcccc}
\hline Tissues & \multicolumn{2}{c}{ Sense strand } & \multicolumn{2}{c}{ Antisense strand } \\
\cline { 2 - 3 } \cline { 2 - 3 } & $\mathrm{C}$ at $\mathrm{CpG}$ & $\mathrm{C}$ at CpN $(\mathrm{N} \neq \mathrm{G})$ & 4.55 & $\mathrm{G}$ at NpG $(\mathrm{N} \neq \mathrm{C})$ \\
\hline Intestine & 0.00 & 0.32 & 1.52 & 0.68 \\
Brain & 1.52 & 0.66 & 1.82 & 0.61 \\
Spleen & 2.10 & 0.49 & 1.52 & 0.36 \\
Liver & 1.52 & 0.53 & 0.00 & 1.01 \\
Eye & 6.36 & 0.48 & 1.52 & 1.12 \\
Kidney & 0.76 & 0.66 & 1.07 & 0.30 \\
Gill & 3.50 & 0.37 & 0.91 & 0.75 \\
Muscle & 1.52 & 0.32 & & 0.55 \\
Heart & 5.68 & 0.40 & &
\end{tabular}

Table 3. Summary of bisulfite sequencing: numbers of unconverted cytosines at each $\mathrm{CpG}$ site.

\begin{tabular}{|c|c|c|c|c|c|c|c|c|c|c|}
\hline CpG position & & Intestine & Brain & Spleen & Liver & Eyes & Kidney & Gill & Muscle & Heart \\
\hline \multirow[t]{2}{*}{1} & Sense strand & $0 / 5$ & $1 / 12$ & $0 / 13$ & $1 / 18$ & $4 / 10$ & $0 / 12$ & $2 / 13$ & $1 / 12$ & $1 / 8$ \\
\hline & Antisense strand & $0 / 8$ & $0 / 6$ & $0 / 10$ & $1 / 18$ & $0 / 13$ & $0 / 9$ & $0 / 6$ & $0 / 17$ & $0 / 10$ \\
\hline \multirow[t]{2}{*}{2} & Sense strand & $0 / 5$ & $0 / 12$ & $0 / 13$ & $0 / 18$ & $0 / 10$ & $1 / 12$ & $0 / 13$ & $0 / 12$ & $0 / 8$ \\
\hline & Antisense strand & $0 / 8$ & $0 / 6$ & $0 / 10$ & $0 / 18$ & $0 / 13$ & $0 / 9$ & $0 / 6$ & $0 / 17$ & $0 / 10$ \\
\hline \multirow[t]{2}{*}{3} & Sense strand & $0 / 5$ & $0 / 12$ & $0 / 13$ & $0 / 18$ & $2 / 10$ & $0 / 12$ & $1 / 13$ & $0 / 12$ & $2 / 8$ \\
\hline & Antisense strand & $1 / 8$ & $0 / 6$ & $0 / 10$ & $0 / 18$ & $0 / 13$ & $1 / 9$ & $0 / 6$ & $1 / 17$ & $0 / 10$ \\
\hline \multirow[t]{2}{*}{4} & Sense strand & $0 / 5$ & $0 / 12$ & $2 / 13$ & $0 / 18$ & $1 / 10$ & $0 / 12$ & $2 / 13$ & $0 / 12$ & $1 / 8$ \\
\hline & Antisense strand & $0 / 8$ & $0 / 6$ & $1 / 10$ & $0 / 18$ & $0 / 13$ & $0 / 9$ & $0 / 6$ & $0 / 17$ & $0 / 10$ \\
\hline \multirow[t]{2}{*}{5} & Sense strand & $0 / 5$ & $0 / 12$ & $0 / 13$ & $1 / 18$ & $0 / 10$ & $0 / 12$ & $0 / 13$ & $0 / 12$ & $0 / 8$ \\
\hline & Antisense strand & $1 / 8$ & $1 / 6$ & $0 / 10$ & $0 / 18$ & $0 / 13$ & $0 / 9$ & $0 / 6$ & $1 / 17$ & $0 / 10$ \\
\hline \multirow[t]{2}{*}{6} & Sense strand & $0 / 5$ & $0 / 12$ & $0 / 13$ & $1 / 18$ & $0 / 10$ & $0 / 12$ & $0 / 13$ & $0 / 12$ & $0 / 8$ \\
\hline & Antisense strand & $0 / 8$ & $0 / 6$ & $0 / 10$ & $0 / 18$ & $0 / 13$ & $0 / 9$ & $1 / 6$ & $0 / 17$ & $0 / 10$ \\
\hline \multirow[t]{2}{*}{7} & Sense strand & $0 / 5$ & $0 / 12$ & $1 / 13$ & $0 / 18$ & $0 / 10$ & $0 / 12$ & $0 / 13$ & $0 / 12$ & $0 / 8$ \\
\hline & Antisense strand & $1 / 8$ & $0 / 6$ & $1 / 10$ & $1 / 18$ & $0 / 13$ & $0 / 9$ & $0 / 6$ & $0 / 17$ & $1 / 10$ \\
\hline \multirow[t]{2}{*}{8} & Sense strand & $0 / 5$ & $1 / 12$ & $0 / 13$ & $0 / 18$ & $0 / 10$ & $0 / 12$ & $0 / 13$ & $0 / 12$ & $0 / 8$ \\
\hline & Antisense strand & $0 / 8$ & $0 / 6$ & $0 / 10$ & $0 / 18$ & $0 / 13$ & $0 / 9$ & $0 / 6$ & $0 / 17$ & $0 / 10$ \\
\hline \multirow[t]{2}{*}{9} & Sense strand & $0 / 5$ & $0 / 12$ & $0 / 13$ & $0 / 18$ & $0 / 10$ & $0 / 12$ & $0 / 13$ & $0 / 12$ & $1 / 8$ \\
\hline & Antisense strand & $0 / 8$ & $0 / 6$ & $0 / 10$ & $0 / 18$ & $0 / 13$ & $0 / 9$ & $0 / 6$ & $0 / 17$ & $0 / 10$ \\
\hline \multirow[t]{2}{*}{10} & Sense strand & $0 / 5$ & $0 / 12$ & $0 / 13$ & $0 / 18$ & $0 / 10$ & $0 / 12$ & $0 / 13$ & $0 / 12$ & $0 / 8$ \\
\hline & Antisense strand & $0 / 8$ & $0 / 6$ & $0 / 10$ & $1 / 18$ & $0 / 13$ & $0 / 9$ & $0 / 6$ & $0 / 17$ & $0 / 10$ \\
\hline \multirow[t]{2}{*}{11} & Sense strand & $0 / 5$ & $0 / 12$ & $0 / 13$ & $0 / 18$ & $0 / 10$ & $0 / 12$ & $0 / 13$ & $1 / 12$ & $0 / 8$ \\
\hline & Antisense strand & $0 / 8$ & $0 / 6$ & $0 / 10$ & $0 / 18$ & $0 / 13$ & $0 / 9$ & $0 / 6$ & $0 / 17$ & $0 / 10$ \\
\hline Myostatin expression* & & + & ++ & - & - & ++ & -- & $+/-$ & +++ & - \\
\hline
\end{tabular}

The ratios (number of methylated cytosines at $\mathrm{CpG}$ ) / (number of sequences examined) are shown. The $\mathrm{CpG}$ positions are defined in Figure 1. *Expression of myostatin mRNA evaluated by RT-PCR (Ye et al., 2007).

\section{Sensitivity of the myostatin gene promoter region to MNase}

Southern blot hybridization analysis was carried out to evaluate the structure of the chromatin in the myostatin gene promoter region. DNA in the heterochromatin would be more resistant to MNase, which primarily degrades naked DNA. Myostatin gene regions in brain and eye, which express myostatin (Ye et al., 2007; indicated at the bottom of Table 3), were highly susceptible to MNase (Figure 2A, B). By contrast, the myostatin promoter region was 
less susceptible in heart, and that in kidney and liver was even more resistant to MNase (Figure 2B-D), which is consistent with the lower level of myostatin gene expression in these organs. We examined several fish individuals for chromatin analyses, and the profiles of MNase digestion were reproducibly observed.

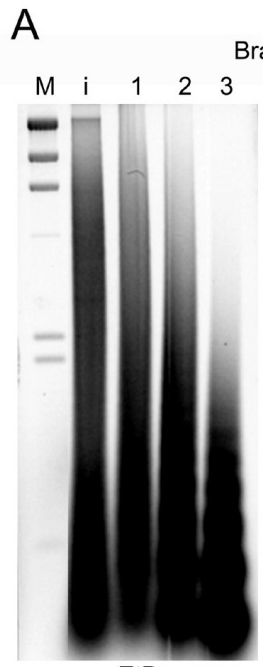

$\mathrm{EtBr}$
Brain i 1123

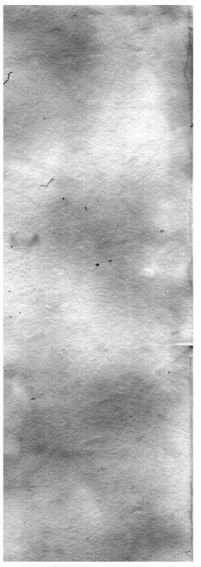

Southern

B
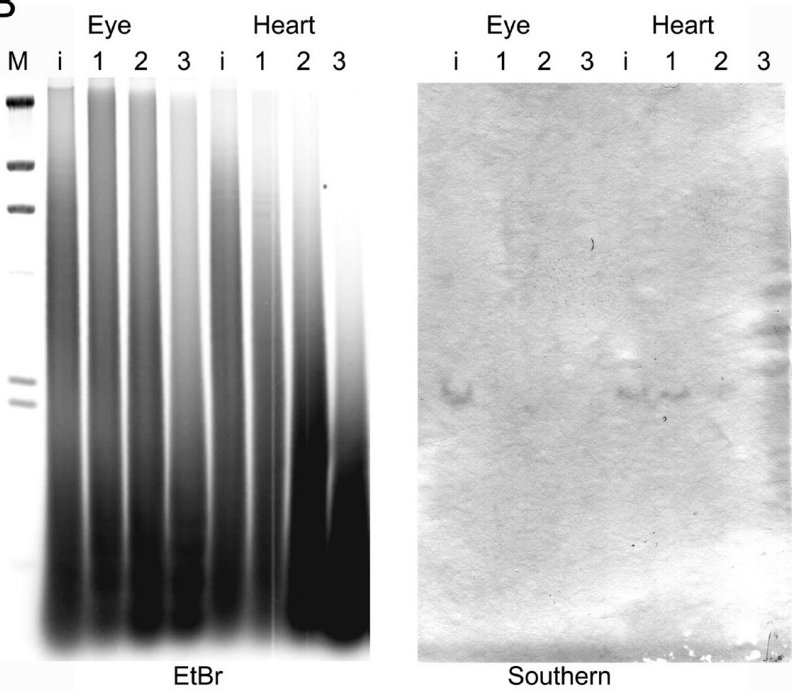

D Liver

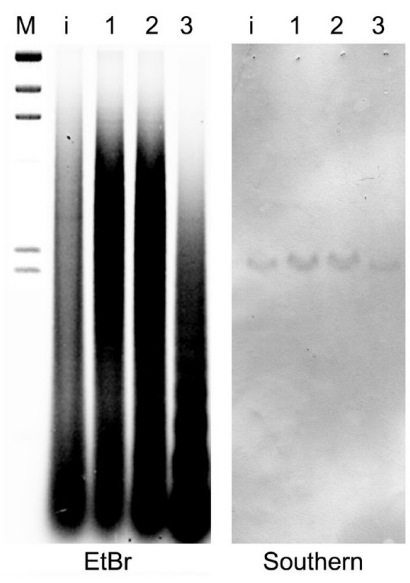

$\mathrm{EtBr}$

Southern

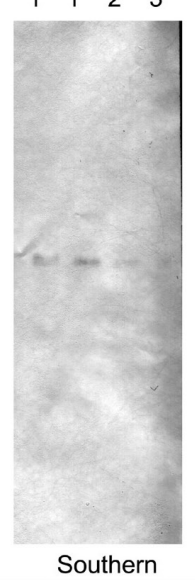

Figure 2. Southern blot analysis of TaqI-digested genomic DNA isolated from MNase-treated cell nuclei. Southern blots were probed with digoxigenin-labeled DNA fragments covering position 682 to 1010 of AY965685. Lane M $=$ Lambda DNA-HindIII digest size marker; lane $i=$ genomic DNA isolated from intact cell nuclei; lane $1=$ DNA fragments isolated from cell nuclei after $15 \mathrm{~min}$ of MNase treatment; lane 2 = DNA fragments isolated from cell nuclei after 30 min of MNase treatment; lane 3 = DNA fragments isolated from cell nuclei after 60 min of MNase treatment. A. Cell nuclei isolated from brain; B. eye and heart; C. kidney; D. liver. 
As widely known, the level of myostatin gene expression is highest in muscle. Currently, we were not able to examine, however, the chromatin structure of the myostatin gene in muscle, because the muscle tissues consist of fibrous proteins (actin and myosin fibers), and the nuclei are destroyed by mechanical shearing and/or the other factors during the homogenization of the muscle. As for gills and intestine, which also express the myostatin gene, the preparation of nuclei contained a high activity of endogenous nuclease, so that the "nucleosome ladders" were not observed after MNase treatment. It was not possible to avoid the effects of nonspecific digestion (shearing, endogenous nucleases, etc.), and these tissues were not submitted to Southern blot analysis.

\section{DISCUSSION}

Although it is known that many active gene promoters in the human genome show little DNA methylation (Weber et al., 2007), DNA methylation at cytosines has not been well studied as an epigenetic trait in fish. There is reportedly the absence of genome-wide changes in DNA methylation during early embryogenesis in zebrafish (MacLeod et al., 1999), although DNA methylation in the promoter region appears to correlate with vitellogenin I gene expression in this fish (Strömqvist et al., 2010). In the medaka fish Oryzias latipes, by contrast, the vast majority of CCGG sites are methylated during early embryonic development, and the extent of the methylation at these sites does not change, or changes very little, during the remaining stages of embryogenesis (Walter et al., 2002).

In the present study, we analyzed the methylation status of the $5^{\prime}$ flanking region of the myostatin gene in various tissues from L. japonicus. Bisulfite treatment and subsequent PCR revealed nearly complete conversion of cytosines to thymines at $\mathrm{CpNs}(\mathrm{N} \neq \mathrm{G})$, so that very few cytosines remained at CpGs (Table 2). This may mean that the methylation system is not utilized for tissue-specific regulation of myostatin gene. Sequence comparison among closely related species has shown that the $5^{\prime}$ flanking regions of myostatin genes are highly conserved (Figure 1). The majority of the variation within these conserved regions is caused by indels at contiguous nucleotides (oligo-C or oligo-A) and transitional substitutions. While several $\mathrm{CpG}$ sites are situated within the conserved regions, transitional substitutions ( $\mathrm{CpG}$ to $\mathrm{TpG}$ or $\mathrm{CpG}$ to $\mathrm{CpA}$ ) are observed in the unconserved $\mathrm{CpG}$ sites. Methylated cytosines tend to change to thymines through spontaneous deamination (Ehrlich et al., 1986), so that 5-methyl-CpG may be substituted by TpG or CpA on an evolutionary time scale. Thus, DNA methylation may not be involved in myostatin gene regulation, but may instead reflect evolutionary processes.

Our MNase assays suggest that the myostatin gene is compacted into heterochromatin in tissues where it is not expressed, such as liver and kidney, whereas it is susceptible to MNase in the eye and brain, which do express myostatin. These results are consistent with the well-known fact that transcriptionally inactive chromatin is relatively resistant to MNase digestion, while openly configured chromatin containing transcriptionally active genes is selectively solubilized by MNase (Tata and Baker, 1978). Our present results suggest that heterochromatinization in tissues where myostatin is not expressed is regulated by mechanisms that do not require DNA methylation.

\section{ACKNOWLEDGMENTS}

The authors thank Ms. T. Adachi for her help in DNA sequencing. E.M. Abbas is sup- 
ported by a scholarship for graduate studies in Japan from the Egyptian Government.

\section{REFERENCES}

Acosta J, Carpio Y, Borroto I, Gonzalez O, et al. (2005). Myostatin gene silenced by RNAi show a zebrafish giant phenotype. J. Biotechnol. 119: 324-331.

Biga PR, Roberts SB, Iliev DB, McCauley LA, et al. (2005). The isolation, characterization, and expression of a novel GDF11 gene and a second myostatin form in zebrafish, Danio rerio. Comp. Biochem. Physiol. B Biochem. Mol. Biol. 141: 218-230.

Clark SJ, Harrison J, Paul CL and Frommer M (1994). High sensitivity mapping of methylated cytosines. Nucleic Acids Res. 22: 2990-2997.

Ehrlich M, Norris KF, Wang RY, Kuo KC, et al. (1986). DNA cytosine methylation and heat-induced deamination. Biosci. Rep. 6: 387-393.

Felsenfeld G and Groudine M (2003). Controlling the double helix. Nature 421: 448-453.

Funkenstein B, Balas V, Rebhan Y and Pliatner A (2009). Characterization and functional analysis of the 5' flanking region of Sparus aurata myostatin-1 gene. Comp. Biochem. Physiol. A Mol. Integr. Physiol. 153: 55-62.

Goll MG and Bestor TH (2005). Eukaryotic cytosine methyltransferases. Annu. Rev. Biochem. 74: 481-514.

Gregory DJ, Waldbieser GC and Bosworth BG (2004). Cloning and characterization of myogenic regulatory genes in three Ictalurid species. Anim. Genet. 35: 425-430.

Helterline DL, Garikipati D, Stenkamp DL and Rodgers BD (2007). Embryonic and tissue-specific regulation of myostatin-1 and -2 gene expression in zebrafish. Gen. Comp. Endocrinol. 151: 90-97.

Jaenisch R and Bird A (2003). Epigenetic regulation of gene expression: how the genome integrates intrinsic and environmental signals. Nat. Genet. 33: 245-254.

Kerr T, Roalson EH and Rodgers BD (2005). Phylogenetic analysis of the myostatin gene sub-family and the differential expression of a novel member in zebrafish. Evol. Dev. 7: 390-400.

Klose RJ and Bird AP (2006). Genomic DNA methylation: the mark and its mediators. Trends Biochem. Sci. 31: 89-97.

Ko CF, Chiou TT, Chen TT, Wu JL, et al. (2007). Molecular cloning of myostatin gene and characterization of tissuespecific and developmental stage-specific expression of the gene in orange spotted grouper, Epinephelus coioides. Mar. Biotechnol. 9: 20-32.

Kocabas AM, Kucuktas H, Dunham RA and Liu Z (2002). Molecular characterization and differential expression of the myostatin gene in channel catfish (Ictalurus punctatus). Biochim. Biophys. Acta 1575: 99-107.

Kuroda A, Rauch TA, Todorov I, Ku HT, et al. (2009). Insulin gene expression is regulated by DNA methylation. PLoS One 4: e6953.

Lee CY, Hu SY, Gong HY, Chen MH, et al. (2009). Suppression of myostatin with vector-based RNA interference causes a double-muscle effect in transgenic zebrafish. Biochem. Biophys. Res. Commun. 387: 766-771.

Lee SJ (2004). Regulation of muscle mass by myostatin. Annu. Rev. Cell Dev. Biol. 20: 61-86.

Li E (2002). Chromatin modification and epigenetic reprogramming in mammalian development. Nat. Rev. Genet. 3: $662-673$.

Maccatrozzo L, Bargelloni L, Radaelli G, Mascarello F, et al. (2001a). Characterization of the myostatin gene in the gilthead seabream (Sparus aurata): sequence, genomic structure, and expression pattern. Mar. Biotechnol. 3: 224-230.

Maccatrozzo L, Bargelloni L, Cardazzo B, Rizzo G, et al. (2001b). A novel second myostatin gene is present in teleost fish. FEBS Lett. 509: 36-40.

MacLeod D, Clark VH and Bird A (1999). Absence of genome-wide changes in DNA methylation during development of the zebrafish. Nat. Genet. 23: 139-140.

Østbye TK, Galloway TF, Nielsen C, Gabestad I, et al. (2001). The two myostatin genes of Atlantic salmon (Salmo salar) are expressed in a variety of tissues. Eur. J. Biochem. 268: 5249-5257.

Østbye TK, Wetten OF, Tooming-Klunderud A, Jakobsen KS, et al. (2007). Myostatin (MSTN) gene duplications in Atlantic salmon (Salmo salar): evidence for different selective pressure on teleost MSTN-1 and -2. Gene 403: 159-169.

Radaelli G, Rowlerson A, Mascarello F, Patruno M, et al. (2003). Myostatin precursor is present in several tissues in teleost fish: a comparative immunolocalization study. Cell Tissue Res. 311: 239-250.

Reik W (2007). Stability and flexibility of epigenetic gene regulation in mammalian development. Nature 447: 425-432.

Rescan PY, Jutel I and Ralliere C (2001). Two myostatin genes are differentially expressed in myotomal muscles of the trout (Oncorhynchus mykiss). J. Exp. Biol. 204: 3523-3529.

Roberts SB and Goetz FW (2003). Myostatin protein and RNA transcript levels in adult and developing brook trout. Mol. Cell Endocrinol. 210: 9-20. 
Rodgers BD and Weber GM (2001). Sequence conservation among fish myostatin orthologues and the characterization of two additional cDNA clones from Morone saxatilis and Morone americana. Comp. Biochem. Physiol. B Biochem. Mol. Biol. 129: 597-603.

Rodgers BD, Weber GM, Sullivan CV and Levine MA (2001). Isolation and characterization of myostatin complementary deoxyribonucleic acid clones from two commercially important fish: Oreochromis mossambicus and Morone chrysops. Endocrinology 142: 1412-1418.

Sambrook J and Russell DW (2001). Molecular Cloning, A Laboratory Manual. 3rd edn. Cold Spring Harbor Laboratory Press, New York.

Sawatari E, Seki R, Adachi T, Hashimoto H, et al. (2010). Overexpression of the dominant-negative form of myostatin results in doubling of muscle-fiber number in transgenic medaka (Oryzias latipes). Comp. Biochem. Physiol. A Mol. Integr. Physiol. 155: 183-189.

Southern EM (1975). Detection of specific sequences among DNA fragments separated by gel electrophoresis. J. Mol. Biol. 98: 503-517.

Strömqvist M, Tooke N and Brunstrom B (2010). DNA methylation levels in the 5' flanking region of the vitellogenin I gene in liver and brain of adult zebrafish (Danio rerio) - sex and tissue differences and effects of 17alphaethinylestradiol exposure. Aquat. Toxicol. 98: 275-281.

Tata JR and Baker B (1978). Enzymatic fractionation of nuclei: polynucleosomes and RNA polymerase II as endogenous transcriptional complexes. J. Mol. Biol. 118: 249-272.

Vianello S, Brazzoduro L, Dalla VL, Belvedere P, et al. (2003). Myostatin expression during development and chronic stress in zebrafish (Danio rerio). J. Endocrinol. 176: 47-59.

Walter RB, Li HY, Intano GW, Kazianis S, et al. (2002). Absence of global genomic cytosine methylation pattern erasure during medaka (Oryzias latipes) early embryo development. Comp. Biochem. Physiol. B Biochem. Mol. Biol. 133: 597-607.

Weber M, Hellmann I, Stadler MB, Ramos L, et al. (2007). Distribution, silencing potential and evolutionary impact of promoter DNA methylation in the human genome. Nat. Genet. 39: 457-466.

Xu C, Wu G, Zohar Y and Du SJ (2003). Analysis of myostatin gene structure, expression and function in zebrafish. $J$. Exp. Biol. 206: 4067-4079.

Ye HQ, Chen SL, Sha ZX and Liu Y (2007). Molecular cloning and expression analysis of the myostatin gene in sea perch (Lateolabrax japonicus). Mar. Biotechnol. (NY) 9: 262-272.

Zhang Y, Jurkowska R, Soeroes S, Rajavelu A, et al. (2010). Chromatin methylation activity of Dnmt3a and Dnmt3a/3L is guided by interaction of the ADD domain with the histone H3 tail. Nucleic Acids Res. 38: 4246-4253. 